\title{
Reviewer Acknowledgements (Vol. 4, No. 2)
}

International Journal of Law and Public Administration (IJLPA) would like to acknowledge the following reviewers for their assistance with peer review of manuscripts for this volume. Many authors, regardless of whether IJLPA publishes their work, appreciate the helpful feedback provided by the reviewers. Their comments and suggestions were of great help to the authors in improving the quality of their papers. Each of the reviewers listed below returned at least one review for this volume.

\section{Reviewers for Volume 4, Number 2}

Andrea Kajcsa, University of Medicine, Romania

Dragoljub Popović, Union University School of Law, Serbia

Encarnación Abad Arenas, National University of Distance Education (UNED), Spain

John Mark R. Asio, Gordon College, Philippines

José Sebastián Kurlat Aimar, University of Buenos Aires, Argentina

Marcin Roman Czubala Ostapiuk, Universidad Nacional de Eduación a Distancia, Spain

Taylisi de Souza Corrêa Leite, Anhanguera University, Brazil

Bennett Brown

Editorial Assistant

International Journal of Law and Public Administration

Redfame Publishing

9450 SW Gemini Dr. \#99416

Beaverton, OR 97008, USA

Tel: 1-503-828-0536 ext. 511

Fax: 1-503-828-0537

E-mail: ijlpa@redfame.com

URL: http://ijlpa.redfame.com 